"Environmental taxes and subsidies: some insights from the Italian experience"

\begin{tabular}{|c|c|c|}
\hline AUTHORS & Andrea Zatti & \\
\hline ARTICLE INFO & $\begin{array}{l}\text { Andrea Zatti (2020). Environme } \\
\text { Italian experience. Environment } \\
\text { doi:10.21511/ee.11(1).2020.04 }\end{array}$ & $\begin{array}{l}\text { sidies: some insights from the } \\
\text { 1), 39-53. }\end{array}$ \\
\hline DOI & http://dx.doi.org/10.21511/ee.11 & \\
\hline RELEASED ON & Wednesday, 13 May 2020 & \\
\hline RECEIVED ON & Thursday, 30 January 2020 & \\
\hline ACCEPTED ON & Monday, 30 March 2020 & \\
\hline & (cc) EY & \\
\hline LICENSE & $\begin{array}{l}\text { This work is licensed under a C } \\
\text { License }\end{array}$ & Attribution 4.0 International \\
\hline JOURNAL & "Environmental Economics" & \\
\hline ISSN PRINT & $1998-6041$ & \\
\hline ISSN ONLINE & 1998-605X & \\
\hline PUBLISHER & LLC "Consulting Publishing Cor & Perspectives" \\
\hline FOUNDER & LLC "Consulting Publishing Cor & Perspectives" \\
\hline & & ニニニ \\
\hline NUMBER OF REFERENCES & NUMBER OF FIGURES & NUMBER OF TABLES \\
\hline 51 & 5 & 2 \\
\hline
\end{tabular}

(C) The author(s) 2021. This publication is an open access article. 


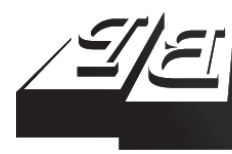

BUSINESS PERSPECTIVES

9

LLC "CPC "Business Perspectives" Hryhorii Skovoroda lane, 10, Sumy, 40022, Ukraine www.businessperspectives.org

Received on: $30^{\text {th }}$ of January, 2020 Accepted on: $30^{\text {th }}$ of March, 2020 Published on: $13^{\text {th }}$ of May, 2020

(C) Andrea Zatti, 2020

Andrea Zatti, Researcher, University of Pavia, Italy.

\section{ENVIRONMENTAL TAXES AND SUBSIDIES: SOME INSIGHTS FROM THE ITALIAN EXPERIENCE}

\begin{abstract}
Environmental taxes and subsidies are considered by the economic theory as useful policy instruments to enhance environmental protection, improve the alignment of prices with full social costs, and encourage sustainable modes of consumption and production. In a policy-oriented perspective, the issue of reforming the financial system in an environmental perspective has attracted increasing attention to the international and European agenda in recent decades. Despite these premises, the actual implementation of environmental fiscal reforms (EFRs) has often lagged behind their full potential and premises. This paper analyzes environmental taxes and subsidies applied in Italy in the last decades to identify priorities, opportunities, and barriers to future developments. Data collected in the main national data sources and reports, as the recently established Catalogue of Environmentally Harmful Subsidies (EHSs) and environmentally friendly subsidies (EFSs), reveal how the implementation and design of taxes and subsidies have been, and still are, mainly driven by non-environmental objectives, leading to mixed and not completely satisfactory effects. In conclusion, relying on these results, some key elements - transparency, graduality, and predictability - may help to overcome the existing barriers to implement and achieve a broader and comprehensive EFR in Italy.
\end{abstract}

Keywords

environmental fiscal reform, environmentally harmful subsidies, public budgets, future developments, selectivity

JEL Classification H23, H60, Q58

\section{INTRODUCTION}

'Environmental fiscal reform', 'Green tax-based reform', 'Green budget-shifting', 'Green fiscal reallocation', 'Green new deal' are all terms extensively used in the recent political agenda to represent efforts to combine budget and environmental objectives and actions explicitly and effectively (Ekins, 1999; EEA, 2011a, b; EEA, 2016; IEEP, 2014; OECD, 2017, 2018). The shared idea is to improve the alignment of taxes and other market-based instruments with environmental externalities, together with socially effective ways of using revenues, and to reform progressively environmentally harmful subsidies, with a specific focus on fossil fuel subsidies. This perspective is relevant due to well-recognized priorities embedded in the economic theory and the statements of several international and national entities: to respect the polluter pay principle (PPP) inserted in several OECD recommendations and the EU treaties; to reflect the full social costs of economic activities (getting the pricing right); to shift the fiscal burden from labor and firms to the exploitation of natural resources and pollution (moving taxation from 'goods' to 'bads').

In this perspective, Italy turns out to be an interesting case study for several reasons. Firstly, because both taxes and subsidies have, in the past, been largely exploited to achieve wider economic and social objectives, often without a full ex-ante and ex-post assessment of their 
level of environmental merit. Secondly, because Italy presents mixed environmental performance, including some areas of great concern (European Commission, 2019) (artificial land coverage, poor implementation quality of nature directives, high concentration of pesticides in surface water, poor air quality). In particular, air pollution continues to give rise to serious health effects, with the second worst figure in the EU in terms of premature deaths. Thirdly, because the recent economic crises exacerbated the need for high-debt countries to find growth-friendly and less distortive ways to correct budget imbalances, reform, and optimize both the revenue and the expenditure side of the public intervention. Finally, because many international organizations and scientific agencies (OECD, 2013, EU, n.d., EEA, 2011a) have recommended that Italy develop its environmental fiscal reform, with the indispensable steps of introducing new green taxes, restructuring the existing ones, and removing the environmentally-harmful subsidies. These recommendations were, at least partially, transposed in 2014 Fiscal Delegation Law ${ }^{1}$ (Article 15), more recently, in 2017 National Strategy on Sustainable Development of December, but no comprehensive and fully aware implementation steps have since been carried out.

In what follows, the author sums up and updates the results of previous studies on the same topic (Zatti, 2017, 2019), gathering some further insights on the effectiveness and political viability of green budget shift efforts. In more detail, section 2 briefly reviews the theoretical debate on this topic. Section 2 describes the main characteristics of environmental taxes and subsidies in Italy, focusing on both quantitative and qualitative aspects. Section 3 discusses the results obtained during the survey. Last section presents some concluding remarks and future implications.

\section{LITERATURE REVIEW}

The use of economic instruments in environmental policies has attracted a wide and increasing attention in the international and European debate (EEA, 2006, 2011b, 2016; European Commission, 1993a, 1993b, 1996, 2001, 2007a, b; OECD, 1989, 1991, 1993, 1994, 1996, 1997, 2001, 2006, 2017). Environmental taxes and subsidies, in particular, have been seen as useful policy instruments to enhance environmental protection, get the price right, and create market-based incentives - price and cost signals for environmentally-friendly behaviors (European Commission, 1996; Ekins, 1999; Leicester, 2006; Fullerton, Leicester, Smith, 2018; Parry, Heine, Lis, \& Li, 2014; OECD, 2017). In this perspective, taxes and other economic instruments acquire, primarily, a regulatory role: they address the market failure of environmental externalities, aligning private and social costs and, consequently, stimulate more socially-desirable outcomes.

Environmental taxes and subsidies also have the effect of generating revenues or new public expenses that can be included in wider projects of greening the public intervention in the economic system. The latter issue has attracted renewed attention in the context of the worldwide economic and environmental crisis, where the opportunity to green budget systems has been seen as a promising tool to obtain more resources to finance new environmentally-friendly expenses, to cut other forms of taxation, or to correct budget imbalances in a more 'growth-friendly' way (European Commission, 2010; OECD, 2017). Budget-shifting programs, also known as environmental fiscal reforms (EFRs) ${ }^{2}$, have remained high on the recent political agenda, as illustrated in the EU's sustain-

1 Law dated March 11, 2014, No. 23, "Delegation of powers to the Government on measures for a more equitable, transparent and growthoriented fiscal system", entered into force on March 27, 2014 and expired, after an extension granted in D.L. 4/2015, on June 27, 2015. Article 15 of the law required an environmental fiscal reform aiming at reorienting the market towards sustainable consumption and production modes.

2 We use here the more general terminology of environmental fiscal reforms (EFRs) that, with respect to environmental tax reform (ETRs), also includes the elimination of environmentally-harmful subsidies (EEA, 2006). The EU supported environmental fiscal reforms since the White Paper of 1993 (Delors): "If the double challenge of unemployment/environmental pollution is to be addressed, a swap can be envisaged between reducing labor costs through increased pollution charges" (European Commission, 1993b, p. 150). The same reasoning has been confirmed by the Europe 2020 strategy: "The revenue side of the budget also matters and particular attention should also be given to the quality of the revenue/tax system. Where taxes may have to rise, this should, where possible, be done in conjunction with making the tax systems more "growth-friendly". For example, raising taxes on labor, as has occurred in the past at great costs to jobs, should be avoided. Rather Member States should seek to shift the tax burden from labor to energy and environmental taxes as part of a "greening" of taxation systems" (European Commission, 2010, p. 24). 
able development goals, the Europe 2020 strategy, as well as in several other international and national policy documents (EEA, 2016; OECD, 2019).

Despite these premises, the actual implementation of EFRs has often lagged behind their full potential (IEEP, 2014; EEA, 2016). In some cases, their design and contents have influenced their effectiveness and impact, which, to date, have been relatively small, leading to marginal changes in the fiscal system. In other cases, the shrinking of environmental tax bases and the non-increase of nominal rates have provoked a progressive downward tendency of revenue shares (Kosonen, 2010; OECD, 2017). As a whole, even acknowledging the presence of different patterns among countries, there remains scope for a wider and more comprehensive diffusion of green budget shifts, overcoming the numerous obstacles to their implementation in terms of competitiveness impact, negative redistributive effects, and political costs of action.

Open and flexible mix of several elements, on both the revenue and the expenditure side, can be implemented to foster these attempts (Zatti, 2017):

- introducing and/or restructuring environmental taxes to improve alignment with external costs (Pigouvian function);

- market creation through the auction of tradeable permits;

- phase out of special measures and subsidies that harm the environment and are socially inefficient;

- periodical evaluation and rationalization of environmentally-friendly subsidies to ensure their economic efficiency3;

- reduction of more distortionary taxes;

- increase of some forms of spending and subsidies favorable for the environment (capi- tal investments in infrastructure directed to environmental protection, environmentally-friendly innovation subsidies);

- explicit mitigation/compensation for categories affected more on the revenue side.

Until now, EFRs have been mainly proposed in the form of revenue-neutral or budget-neutral exercises, but increasing or decreasing fiscal imbalances have also been experienced (Vollebergh, 2014; Eunomia, 2014, 2016; OECD, 2019). Well-designed policy packages, comprising newly-introduced fiscal instruments and earmarked use of revenues can make sense to increase transparency and the overall environmental result. It is, however, important that decisions on revenue use should not guide how environmentally-related instruments are designed or at which level they are set. Rigid constraints on how to use revenues should also be avoided since they risk resulting in inefficient public spending, above all, in the long run (IEEP, 2014; OECD, 2017)

\section{GENERALIZATION OF THE MAIN STATEMENTS}

\subsection{Environmental taxes within the Italian fiscal system}

The Italian fiscal system is largely based on labor income taxes. In 2017, these accounted for 49.2 percent of total collected revenues (20.7 percent of GDP). Values declined slightly from $2008(-1.3 \%)$ in terms of total revenues but are still much higher if compared to 1995: +3.7 percent of total collected revenues and +3.3 percent of GDP. Basically, in 2017, these values translate into an implicit tax rate on labor of 42.4 percent: the second highest in Europe and well above the European average (36.3 percent in the EU-28 and 38.6 percent in the Euro area).

3 "In some cases, subsidies have been identified which appear to be not so much 'environmentally-harmful subsidies', but 'fiscally-inefficient environmental subsidies'. These are subsidies that are offered to support environmental activities, but in ways that might not be the most efficient, effectively allowing rents to accrue on the part of beneficiaries. The ongoing debate, in several Member States, around the appropriate levels of support for renewable energy provides a good example of such discussions" (Eunomia, 2014, pp. 13-14). Similarly, the OECD Environmental Performance Review for Italy (2013) recommends that consistency with the incentive system be guaranteed, addressing decreasing costs in technologies for producing renewable energies, and to rationalize the governance and management of the incentive systems for energy efficiency and renewables (Lapecorella \& Douvan, 2014) 
Table 1. Revenue breakdown of environmental taxes in Italy in 2017

\begin{tabular}{|c|c|c|}
\hline & EUR million & $\%$ of total environmental taxes \\
\hline Energy & 45,662 & 79.6 \\
\hline Tax on mineral oils and related product consumption (excise duty) & 26,134 & 45.5 \\
\hline Tax on non-condensable gases of oil products & 645 & 1.1 \\
\hline $\begin{array}{l}\text { Excise duty on electricity and system charges on electricity bill for } \\
\text { supporting renewable energy sources }\end{array}$ & 14,354 & 25 \\
\hline Taxes on natural gas consumption (excise duty) & 3,863 & 6.7 \\
\hline Tax on coal consumption (excise duty) & 29 & 0.1 \\
\hline $\begin{array}{l}\text { Fee on sales of energy sector operators established to finance the } \\
\text { Authority for Electricity, Gas and water system }\end{array}$ & 51 & 0.1 \\
\hline Revenue from emission allowance auctioning & 549 & 1 \\
\hline Others & 37 & 0.1 \\
\hline Transport & 11,036 & 19.2 \\
\hline Vehicle registration tax & 1,801 & 3.1 \\
\hline Vehicle civil liability insurance premium tax & 2,471 & 4.3 \\
\hline Annual tax on vehicle ownership (households) & 5,200 & 2.7 \\
\hline Annual tax on vehicle ownership (companies) & 1,553 & 9.1 \\
\hline Taxes on aircrafts, aerotaxis, and boats & 11 & 0.1 \\
\hline Pollution & 686 & 1.2 \\
\hline Landfill tax & 258 & 0.4 \\
\hline SOx and NOx pollution tax & 5 & 0 \\
\hline Provincial tax for environmental protection & 417 & 0.7 \\
\hline Tax on aircraft noise & 6 & 0 \\
\hline Resources & 0 & 0 \\
\hline Total & 57,384 & 100 \\
\hline
\end{tabular}

Not surprisingly, the high weight of labor income taxes is reflected in the circumstance that taxes on consumption play a minor role. In 2017, they accounted for 26.6 percent of total collected revenues (11.2 percent with respect to the GDP), below the Euro Area average of 26.9 percent and the EU-28 average of 28.3 percent in terms of total revenues, but higher with respect to GDP (10.8 and 11.1 percent, respectively). In the same year, the implicit tax rate on consumption was 18.3 percent, well below the Euro-19 average of 20.6 percent and the EU-28 average of 20.7 percent.

As far as environmental taxes are concerned, Istat (Italian Institute of Statistics) reports the Italian overall situation periodically, with the common breakdown into four categories: energy, transport, pollution, and resources (Table 1), but without considering the breakdown among different levels of government (Carraro \& Zatti, 2012).
Pollution taxes, explicitly introduced for environmental purposes (genuine Pigouvian levies), represent a very small share (1.2\%) of total environmental tax revenues, while no resource tax is reported in the database. Energy taxes (which embrace taxes on transport fuels) and transport taxes represent by far the largest categories, accounting for, 79.6 and 19.2 percent of the total, respectively.

Energy and transport levies have been mainly introduced and maneuvered for revenue-raising purposes, with priorities other than environmental ones in mind (budget objectives, coping with natural disasters, income distribution, inflation control, industrial competitiveness, etc.). More recently, environmentally-related concerns increasingly influenced the implementation and design of new instruments - as in the case of the auctioning of tradable permits ${ }^{4}$ and the introduction of a specific levy in the electricity bill for supporting renewables (A3 component) - or the revision of existing ones. For example, vehicle registration

4 According to Eurostat (2018), revenues generated from the auctioning of emission allowances are treated as tax receipts in national accounts and should also be listed under the heading 'energy taxes'. The inclusion of these revenues in the category 'energy' is questionable since their amount is strictly related to the carbon content of different fuels (similarly to pollution taxes) and that their application is not strictly limited to the energy sector. 
Source: Author's elaborations on the data from Istat (2019, online database) and Eurostat (2018).

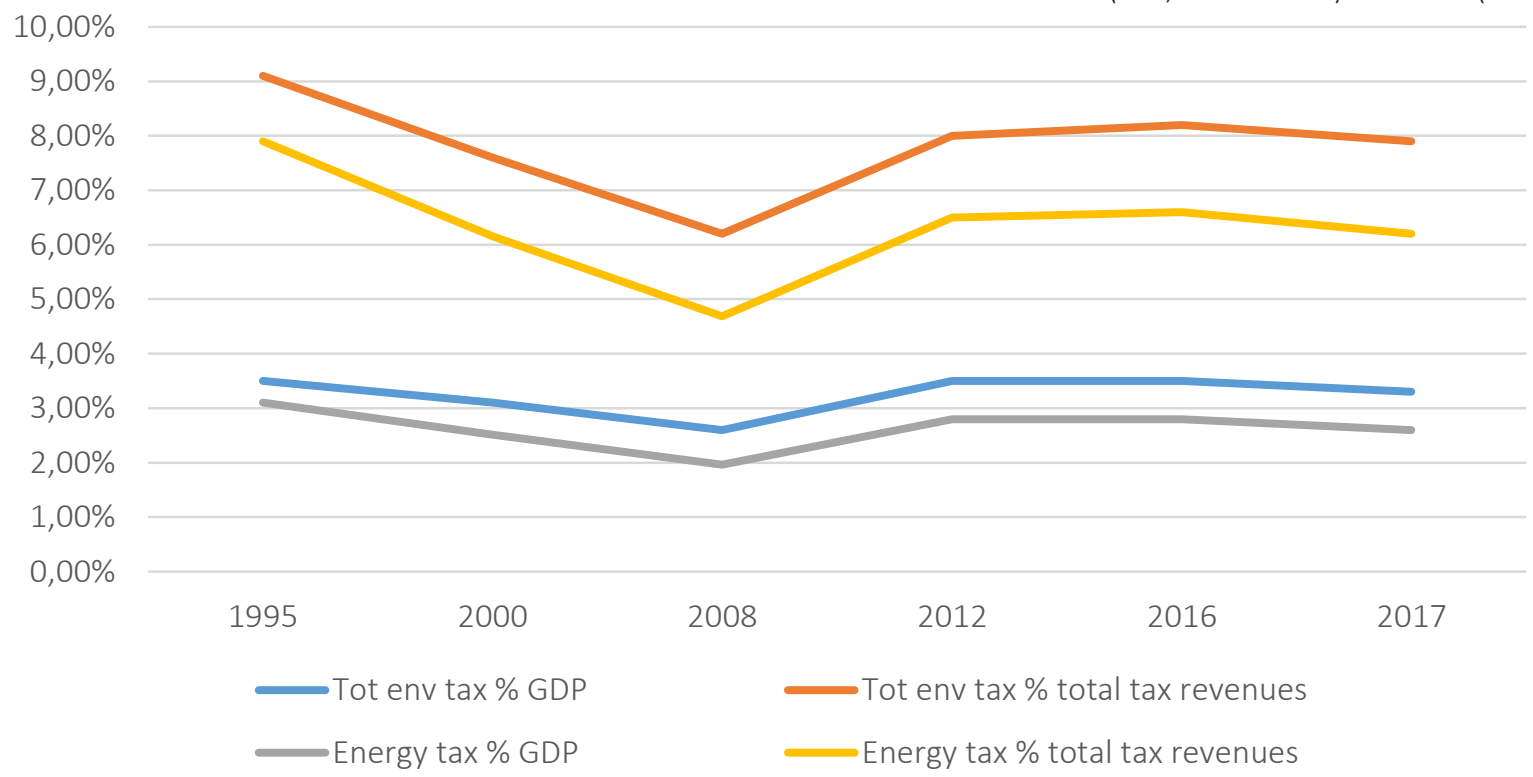

Figure 1. Environmental tax revenues (Italy, trend 1995-2017)

taxes and ownership taxes have been progressively revised to penalize more powerful cars, while, in the case of the recurrent ownership levy, the environmental class of the vehicle is also taken into consideration (Zatti, 2017).

In 2017, revenues from environmental taxes represented 3.3 percent of GDP (against an EU-28 average of 2.4 percent), and 7.9 percent of total tax revenue collected (6.1 percent in the EU-28 average) ${ }^{5}$. Those values are the 7 th and 11th highest, respectively, in the EU-28 ranking. Historically, Italy, in the early nineties, had one of the highest shares of environmental taxes, even higher than the Nordic countries. In this period, an innovative approach was implemented with the introduction of several new environmental taxes, for example, on air pollution (large industrial plants), waste, plastic bags, pesticides, and landfills.
In the last two decades, the role of green taxbased levies experienced a U-shaped development (Figure 1), with a downward trend until 2008, mainly as a result of the absence of rate adjustments in line with inflation, followed by a substantial rise, up to 2014, and a more recent stabilization (Zatti, 2019).

In Italy, the dynamic can be largely traced back to the use of energy taxation ${ }^{6}$. Initially implemented mainly for budget needs, the revenues collected through energy taxation accounted for more than $3 \%$ of GDP ( $8 \%$ of total tax revenues) until the mid-nineties, but subsequently decreased to $1.9 \%$ in 2008. During the recent economic crisis, energy taxation rose again, reaching $2.6 \%$ of GDP and $6.3 \%$ of total tax revenues collected in 2017. Considering the real implicit tax rate (ITR) on en$\operatorname{ergy}^{7}$, the recorded values substantiate the idea of

5 Differences and comparisons across European countries should be interpreted with caution (Kosonen, 2010). Low government revenue from environmentally-related taxes could be caused by relatively low tax rates in a given country. However, it could also result from the reduction of the tax bases (environmentally-harmful consumption or activities) triggered by high and effective tax rates. One further issue might arise when traditional taxes are substituted with other instruments that do not involve revenue collection (this is the case of regulation) or that are not easily and systematically computed in the national database (as happens with road-pricing initiatives or the implementation of local taxes).

6 Duties on transport fuels account for nearly $60 \%$ of the energy taxes implemented.

7 The real implicit tax rate on energy is defined as the ratio of energy tax revenues to final energy consumption calculated for a certain year. Energy tax revenues are measured in constant price euros (deflated with the implicit GDP deflator), and final energy consumption is measured in tons of oil equivalent; as such, the implicit tax rate on energy is expressed in terms of euros per ton of oil equivalent. The implicit tax rate on energy is not influenced by the size of the tax base and provides a measure of the effective level of energy taxation. The reason for focusing on this indicator is that final energy consumption can be accounted for with a unique unit of measurement: the net calorific value. The possibility to construct an implicit tax rate for environmental taxes overall is, on the contrary, troublesome because of the diversity of tax bases (pollution, natural resources exploitation, car ownership, etc.). However, energy taxes represent by far the largest category of environmental taxation, making this indicator a good proxy of the overall trend. 

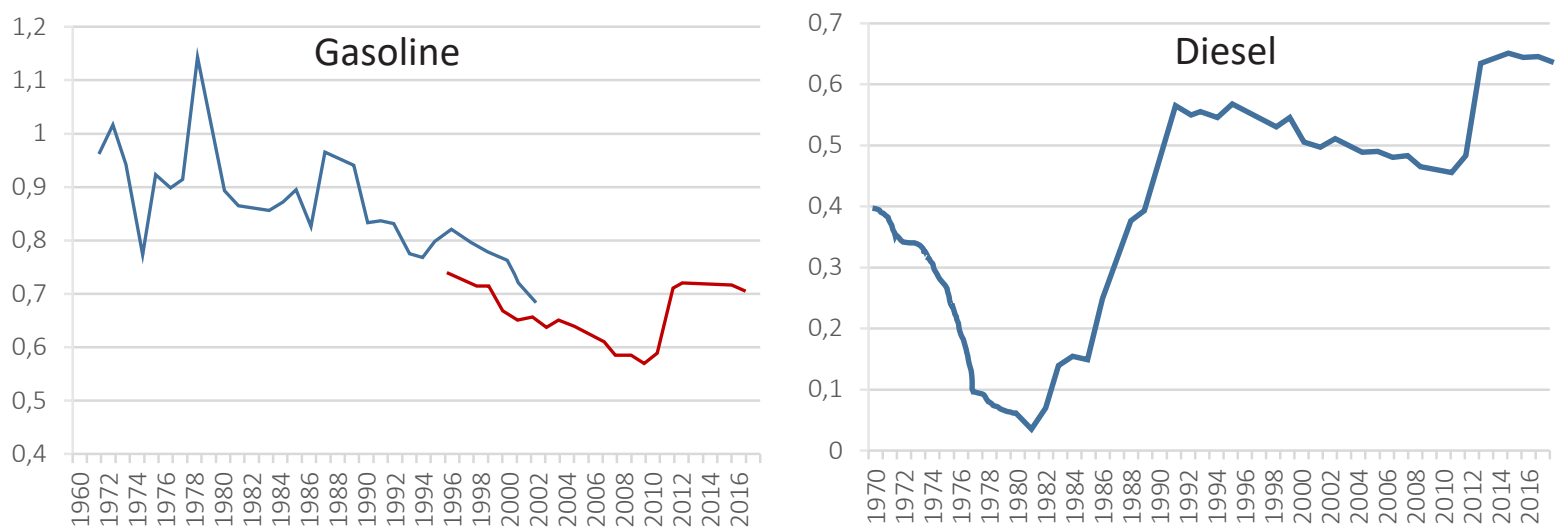

Figure 2. Excise duties on gasoline and diesel (EUR per liter, real prices in 2017)

a high and rising energy taxation regime, mostly composed of excise duties on mineral oils. The implicit tax per ton of the oil equivalent (EUR 373 in 2017) is, in fact, second only to Denmark (EUR 391 ), and has experienced a $30 \%$ increase in the period 2009-2017. In this trend, mainly, two factors played a key role.

On the one hand, as a consequence of worsening Italy's position on the financial markets, the government approved in 2011 a budget package named 'Salva Italia', including certain measures regarding environmental-related taxes (adjustment of excise taxes on motor fuels and the new tax on high-powered vehicles and boats). In particular, the rate for diesel was rapidly increased from 423 to 617 Euros/thousands of liters, so that the differential to gasoline was narrowed considerably (Figure 2).
On the other hand, the revenues collected through the financial surcharge included in the electricity tariff to support renewables (the so-called A3 component, Figure 3) increased from EUR 3.1 billion in 2009 to EUR 14.4 billion in 2016: an evolution representing $3 / 4$ of the total increase of environmental taxes in current prices from 2009 to $2016^{8}$.

The evolution of the ratio of labor taxes to environmental taxes can be useful in evaluating the coherence of the Italian trend with the recurrent objective of moving towards the logic of the socalled green fiscal reforms. Figure 4 reveals an increasing trend up to 2008 for Italy, when labor tax was 8.6 times environmental tax, followed by a radical change of direction in recent years when, unlike the rest of the EU, a non-negligible green tax shift trend emerged. In a budget consolidation period - when total taxation to GDP increased by

Source: GSE (2019).

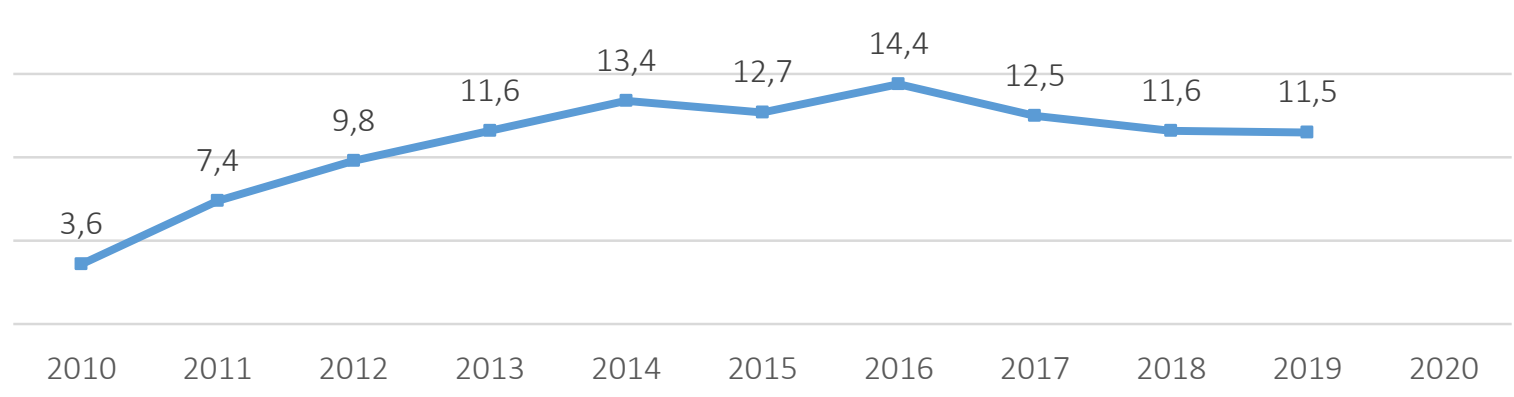

Figure 3. Total cost of $A 3$ component for supporting renewable sources, Italy (EUR billion, 2009-2018)

8 Similarly, for France, it is reported that "La remontée de la part des taxes vertes dans le PIB depuis 2009 s'explique quant à elle par la création de l'imposition forfaitaire sur les entreprises de réseaux (IFER, mise en place en 2010) et le dynamisme de la contribution au service public de lélectricité (CSPE). Cette dernière finance notamment les subventions à l'achat délectricité produite à partir d’énergie renouvelable (éolien, photovoltaïque, etc.), et a accompagné le développement de ces énergies: son montant est passé de 1,7 MdEURO en 2009 à 6,6 MdEURO en 2015" (Ministere de l'Environnement, de l'Energie et de la Mer, 2017, p. 23). 


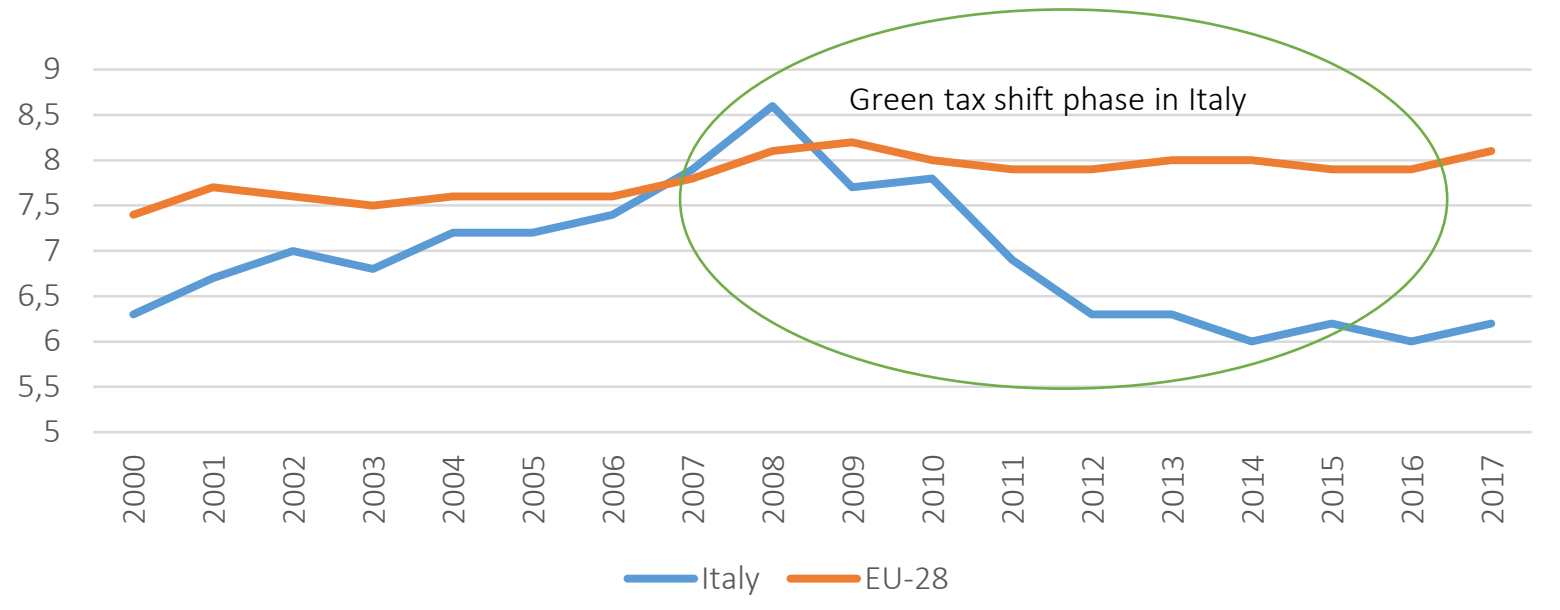

Figure 4. Labor tax/environmental tax (2000-2016)

1.4\% from 2008 to 2016 - this shift has permitted labor tax revenues to GDP to be kept steady, without a further burden on the most charged productive factor.

\subsection{Environmentally-harmful and environmentally-friendly subsidies (EHSs and EFSs): the Italian Catalogue}

Starting from the fiscal reform of the seventies, several governments have scrutinized the role of on-budget subsidies and tax expenditures to decrease their number and keep only those related to strategic and socially-beneficial goals. In the last decade, the Working Group on Tax Erosion (socalled Ceriani Commission (Gruppo di Lavoro sull'Erosione Fiscale, 2011)) has started to analyze in detail the tax expenditures within the Annex to the Budget Law to identify the areas of possible intervention. In 2017, the Committee that assists the government in monitoring tax expenditure found a total of as many as 610 different measures (468 measures regarding state taxes and 166 regarding local taxes), with a financial impact equal to -EUR 76.5 billion for public budgets (Impact Assessment Office, 2017b). This amount is deemed to be a serious underestimate since no quantitative information is available on about $2 / 3$ of state tax expenditures.
In the environmental field, a specific focus was introduced by the National Law 221/2015 ${ }^{9}$ that provided (Art. 68) for the establishment of a Catalogue on Environmentally Harmful and Environmentally Friendly Subsidies (CES), to be transmitted to the parliament annually. According to the approach adopted in the Catalogue, subsidies are considered in their broader definition, including incentives, benefits, backed loans, and tax exemptions and credits concerning taxes related to environmental protection.

The Catalogue aims to identify, classify, and quantify the amount of support that might imply any relevant environmentally-harmful environmentally-friendly impact. The Catalogue is seen as a tool to help the parliament and the government to implement the 2014 reform for a fairer, transparent, and growth-oriented tax system. It explicitly aims, from general to specific (Ministry of the Environment, Land and Sea, 2016, pp. 6-7, 12) to contribute to possible reform of the overall taxation system, according to the Polluter Pays Principle; to improve allocative efficiency; to identify measures able to contribute to an environmental fiscal reform; to identify areas of possible reduction of fiscal expenditures in general; to begin a "gradual, although quick and well-defined" path towards eliminating the environmentally-harmful subsidies; to improve the effectiveness and efficiency of environmentally-friendly subsidies.

9 "Environmental measures for promoting green economy and limiting the excessive use of national resources (Annexes to the StabilityFinancial Law). 
Table 2. Estimates of total amount of subsidies by sector and typology (2017, EUR million)

\begin{tabular}{|c|c|c|c|c|}
\hline & Harmful (EHSs) & Friendly (EFSs) & Uncertain & Total \\
\hline \multicolumn{5}{|c|}{ Agriculture } \\
\hline Tax expenditures & 7.49 & 3.8 & 294.7 & 305.99 \\
\hline Direct subsidies & 271.92 & $1,331.79$ & $4,027.15$ & $5,630.86$ \\
\hline Total & 279.41 & $1,335.59$ & $4,321.85$ & $5,936.85$ \\
\hline \multicolumn{5}{|c|}{ Energy } \\
\hline Tax expenditures & $11,396.86$ & 83.2 & 76.0 & $11,556.06$ \\
\hline Direct subsidies & 840.53 & $12,032.40$ & N/A & $12,872.93$ \\
\hline Total & $12,237.39$ & $12,115.60$ & 76.0 & $24,428.99$ \\
\hline \multicolumn{5}{|c|}{ Transport } \\
\hline Tax expenditures & $1,434.7$ & 3.0 & & $1,437.7$ \\
\hline Direct subsidies & & 35 & 64.1 & 99.1 \\
\hline Total & $1,434.7$ & 38 & 64.1 & $1,536.8$ \\
\hline \multicolumn{5}{|c|}{ Other subsidies } \\
\hline Tax expenditures & 655.30 & $1,663.84$ & 215.1 & $2,534.24$ \\
\hline Direct subsidies & N/A & 10.86 & 479.15 & 490.01 \\
\hline Total & 655.30 & $1,674.70$ & 694.25 & $3,024.25$ \\
\hline \multicolumn{5}{|c|}{ Reduced VAT } \\
\hline Tax expenditures & $4,684.75$ & 26.73 & $1,416.00$ & $6,127.48$ \\
\hline Total & $4,684.75$ & 26.73 & $1,416.00$ & $6,127.48$ \\
\hline \multirow{2}{*}{ Total } & $19,291.55$ & $15,190.62$ & $6,572.2$ & $41,054.37$ \\
\hline & $47 \%$ & $37 \%$ & $16 \%$ & $100 \%$ \\
\hline
\end{tabular}

The overall results of the second assessment by the Italian Ministry of the Environment, Land and Sea (2018) are summarized in Table 2. 161 subsidies have been identified for a total financial effect of almost EUR 41 billion, divided into five sectors: Agriculture, Energy, Transport, Other subsidies ${ }^{10}$, Reduced VAT. In this second release, EHSs and EFSs amount to EUR 19.3 billion (47.0 percent of the total) and EUR 15.2 billion (37.0 percent), respectively. A non-negligible share of subsidies (EUR 6.6 billion, 16.0 percent of the total), mainly represented by investments granted by the Common Agricultural Policy, is deemed to be uncertain.

As far as EHSs are concerned, measures are mostly identified in the energy sector (Figure 5), with six main categories involved:

- exemption from excise on electricity used in residential homes with a power capacity up to $3 \mathrm{~kW}$ and monthly consumption up to 150 kWh (EUR 634 million);
- emission trading scheme allowances allocated free of charge (EUR 394.63 million), estimated by considering an average price allowance in 2017 of EUR 5.8/tCO ${ }_{2}{ }^{11}$. Since revenues obtained by auctions are earmarked to a special fund to finance measures to fight climate change, free allocation causes a double loss: on the one hand, it weakens the economic incentive to reduce emissions and, on the other hand, it cuts resources that can be spent for environmentally-friendly purposes;

- reduced excise duties for diesel and gasoline ( $22 \%$ and $49 \%$ of ordinary rate, respectively) used as fuels in agriculture (EUR 843 million);

- exemptions from excise duties on fuels used for marine navigation ${ }^{12}$, inland waterways and aviation $^{13}$ (total EUR 2,102 million);

- excise duties refund for freight transport for excise duties increases adopted after 2000

10 Building, water and waste, manufacturing, fishing.

11 It must be considered that, at the beginning of 2020, the auction price has risen steadily, reaching EUR 24.

12 Excluding private pleasure boats.

13 Domestic and intra-EU flights are formally subject to the EU-ETS scheme while, in the case of extra-EU flights, the application has been suspended. 
(EUR 1,257 million), mainly justified by the need to compensate national transport operators for the high level of excise duties paid compared to neighboring countries;

- favorable excise duty treatment for diesel compared to gasoline (EUR 4,910 million). In Italy, the nominal excise duty for diesel vehicles is lower, by nearly $15 \%$, than the gasoline duty. Considering the energy content, diesel excise is lower by $23 \%$ in terms of euro per GJ. This difference is not justified from an external cost approach since it is widely acknowledged (OECD, 2013; EEA, 2015; Camporeale et al., 2018) that externalities associated with diesel are higher than gasoline, giving a good reason for higher taxation. This is considered an implicit subsidy whose elimination at the top could increase total revenues by nearly EUR 5 billion ${ }^{14}$. Even the gradual alignment half-way between the two rates, with a decrease of the excise duty of gasoline and an increase of the excise duty on diesel, will have a net positive effect on fiscal revenues (EUR 800 million) due to the recent process of dieselization of transport-related consumption.

The overall magnitude of energy-related tax expenditures is further increased by the fact that the two most significant VAT tax expenditures (total EUR 3,067 million) correspond to the reduced rates of VAT ( $10 \%$ vs. the normal rate of $22 \%$ ) applied on energy products used for domestic use and for industrial processes ${ }^{15}$.

Outside the energy sector, the most important EHS (estimated EUR 1,200 million) is represented by the favorable tax treatment accorded to employees for the fringe benefit derived from company cars private use (Zatti, 2017). The use of the company in Italy is taxed on a flat-rate basis, assuming a yearly traveled distance of $4,500 \mathrm{~km}$ per personal purpose. That approach, on the one hand, underestimates the value of the personal benefit, and, on the other hand, not varying with the distance driven, provides an incentive to travel longer trips (Harding, 2014).
As a whole, more than $94 \%$ of EHSs are tax expenditures, often introduced many years ago for social and competition-related purposes, but causing a relevant negative environmental impact as side effects. This huge amount of foregone revenues represents an attractive prospect for future green budget reallocation initiatives, even if its concrete maneuverability, at least in the short term, must be assessed with caution for several reasons. Firstly, from a strictly environmental point of view, because the demerit of some of the subsidies included in the Catalogue is uncertain. This is the case of the excise exemption for electricity used in urban and intercity lines of public transport, which, supporting collective means, may reduce the use of private cars and, consequently, urban pollution and congestion. Also, the exemption from excise on electricity used in residential homes is seen as a measure that may have encouraged many final consumers to keep their power capacity below the $3-\mathrm{kW}$ threshold, contributing to a lower, and not a higher, energy intensity (Ministry of the Environment, Land and Sea, 2016). Secondly, because, to phase out the major typologies of EHSs, an exhaustive ex-ante multi-criteria analysis should be carried out to compare benefits and costs, focusing on the original goals of its introduction, as well as direct and indirect beneficiaries and sectors penalized by their existence or abolition. The Catalogue needs to be interpreted, from this point of view, as a tool to support transparent and updated decisional procedures, able to screen systematically direct and indirect subsidies in terms of net social welfare. Finally, because the most relevant measures affect sensitive categories and sectors (agriculture, freight transport, final energy consumers), requiring well-structured compensation or mitigation measures and policy packages to be truly politically feasible.

Direct on-budget subsidies mainly constitute EFSs (88\%), specifically introduced to pursue environmentally-related goals. The support schemes to photovoltaic plants and other renewable energy sources represent the largest amount (EUR 12,032 million in 2017). The $65 \%$ deduction allowed for

14 The amount is estimated applying the existing diesel/gasoline gap in terms of euros/GJ (EUR 5) to the total Italian consumption of diesel in 2017.

15 Other valuable categories are represented by the reduced 10\% VAT rate on water (EUR 682 million) and 4\% on fertilizers (EUR 535 million). 


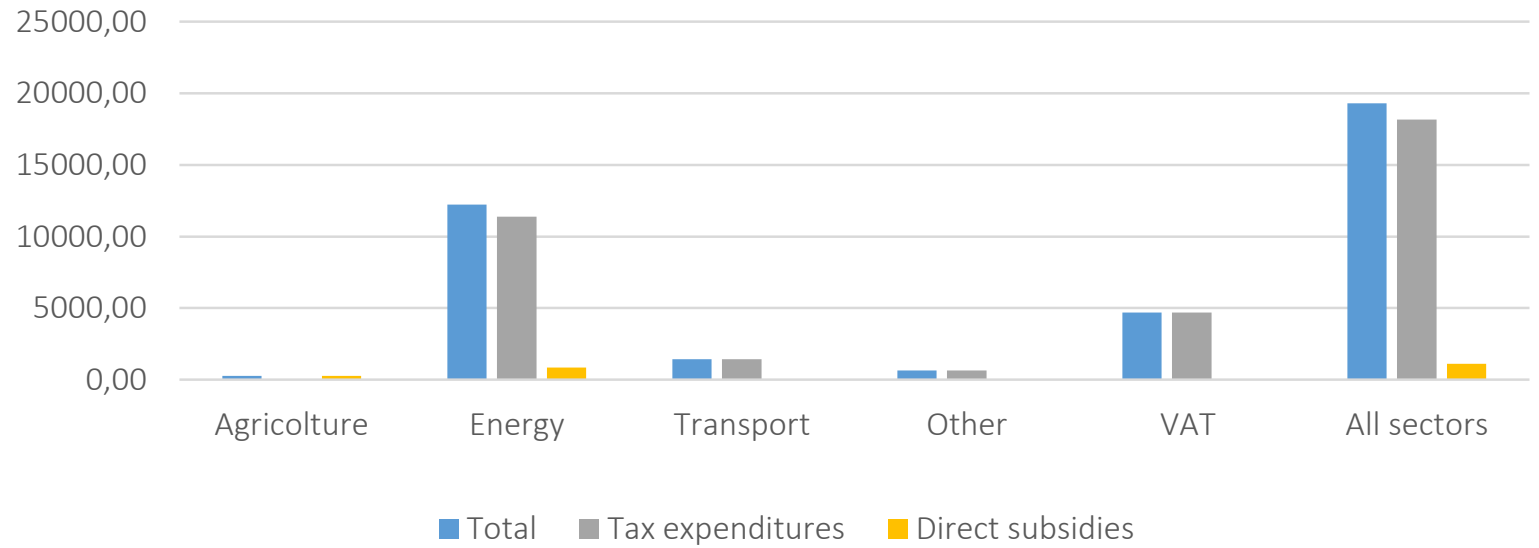

Figure 5. Environmentally-harmful subsidies (EHS) by sector and typology (2017), EUR million

energy-saving interventions for the existing buildings gives rise to nearly EUR 1.4 billion of foregone revenues included in the category "Other sectors", but even in this case strictly related to energy consumption and saving.

To conclude, several tax expenditures and direct subsidies are classified as uncertain, in the sense that the environmental impact generated or triggered by each instrument is not fully computable as positive or negative. Numerous direct payments in agriculture (nearly EUR 4 billion), granted to farmers to stabilize incomes and/or to support specific productions or practices, are deemed to be uncertain. This assessment, following a recent evaluation of the Court of Auditors ${ }^{16}$, includes also funds (EUR 1.2 billion) given within the so-called greening of the EU Common Agricultural Policy.

While the attention of budget-shifting programs has been traditionally focused on the abolition of EHSs, in the author's opinion, the improvement of the environmental and, more generally, welfare performance of favorable and uncertain subsidies should also not be neglected. For example, the support given to renewable energy can be adapted to consider decreasing technology costs and learning curves ${ }^{17}$; as can tax expenditures implemented to improve the energy performance in existing buildings be designed to reward deeper and more cost-effective solutions ${ }^{18}$. In the same way, agricultural subsidies, or other grants and tax credits implemented in the manufacturing sector ${ }^{19}$, can be reformed through more selective criteria to improve their level of environmental merit, favoring their possible future conversion into EFSs. This opportunity, being mainly based on the restructuring of existing instruments and not creating new expenses or costs for taxpayers and final users, can probably be a more viable option in terms of political acceptability and less adverse redistributive effects compared to the sole elimination of EHSs.

It should also be considered that many measures, above all, in terms of on-budget subsidies, have not yet been quantified in the Catalogue. This makes the existing analysis a work in pro-

16 According to the conclusions of this report, the greening, as currently implemented, is unlikely to meet the original environmentallyfocused objective, mainly due to the inadequate level of adopted parameters, largely reflecting the normal farming practice (European Court of Auditors, 2017).

17 In the Foreword of the Italian Catalogue, it is expressly stated that: "it is important to continue to improve the effectiveness and efficiency of environmentally friendly subsidies to which our country already devoted in the past, at least in the case of renewable energy sources, substantial funds. Nevertheless, we need to guarantee stable and certain incentives through time, while orienting public expenditure to the funding of environmentally sustainable technological innovation" (Ministry of the Environment, Land and Sea, 2016, p. 9).

18 In France, it is observed that "le évaluations disponibles suggèrent de moduler les taux en fonction du niveau de performance énergétique des équipements acquis et des travaux réalisés, par le biais d'une sélectivité forte des travaux et equipements elegibles, couplee a des taux des prix en charge élèves" (Ministere de l'Environnement, de l'Energie et de la Mer, 2017, p. 48).

19 As in the case of tax credits awarded to purchase new instrumental assets as production facilities for specific sector and/or geographical areas. 
gress, with interesting future developments, above all, through the inclusion of some further categories: tax expenditures and grants recently introduced; EU structural funds implemented within National Operational Programmes and Regional Operational Programmes; direct subsidies and tax expenditures established by sub-national governments (regional and local); subsidies introduced for the provision of public infrastructures and services; subsidies, even under the form of export credit guarantees, implemented under foreign assistance programs in third countries.

\section{DISCUSSION}

Results of the survey show how, in Italy, environmental taxes and subsidies are widely used in several sectors of the economy, notably the transport sector (including transport fuels), the energy sector (above all, at the consumption level), the agriculture sector, and much less in other sectors. Yet, their introduction and design have been, and still are, often driven by non-environmental objectives, leading to mixed and not completely suitable results.

Considering this background, environmental fiscal reform and a green tax shift still hold considerable promise.

From a quantitative point of view, the country-specific surveys and analysis till now carried out (EEA, 2011a; Eunomia, 2014, 2016; Ministry of the Environment, Land and Sea, 2018; Zatti, 2017, 2019; OECD, 2019) reveal a hypothetical revenue potential from 0.5 to 2 percentage points of GDP, obtainable by the greening of existing taxes, the introduction of new environmental taxes and/or the reform of current subsidies. Although some space to increase revenues can be realistically exploited, for example, reaching the target of $10 \%{ }^{20}$ of environmental taxes as a percentage of total taxation, the revenue-generating potential should not be considered the primary driving force of future initiatives. As pointed out in section 2, Italy has, in fact, a high level of overall taxation, of energy taxation in particular, and the growth of environmental tax revenues have exceeded the development of GDP and labor-tax revenues since 2008-2009 economic and financial crisis. Furthermore, to be politically feasible, many of the measures considered can be implemented only gradually and require compensation and accompanying measures that will necessarily weaken the net budget effect. Finally, it must be considered that tax base erosion for transport fuels and energy consumption will play an increasing role with technology improvements, behavioral changes, and energy and climate policy reduction targets, leading to uncertain medium- and long-term effects on revenues.

Taking these premises into consideration, the key objective of future initiatives seems to be that of selectivity, rather than quantitative growth: i.e. that of tackling environmental challenges in an effective way, progressively aligning taxes to reflect environmental damage, benefits, and priorities closer, and better integrating the different fiscal instruments applied to the same theme/sector. Several options have been identified to improve the existing situation: better articulate vehicle taxes in line with GHG emissions, reduce the favorable (and unreasonable) treatment of company cars, bring taxes into line with the energy and environmental content of fuels, progressively affect the fiscal privilege granted to marine navigation and aviation, shift energy taxes from consumption to production, improve the environmental merit of funds granted to the agriculture sector, promote a more coherent use of fiscal levies on the use of exhaustible resources (water, aggregates, gas and oil, land use). Selectivity and detailed ex-ante and ex-post screening are also promising to phase out EHSs, mainly represented by tax expenditures, and to reform on-budget transfers (both environmentally-friendly and neutral) to improve their overall efficiency in a wholly revenue-neutral way. The huge renewable energy support and the deduction for energy-saving refurbishments of the existing buildings are at present the main possibilities of intervention in this last field.

20 Benchmark value in the "Resource Efficient Europe" Flag Initiative within the Europe 2020 strategy. 


\section{CONCLUSION}

This paper describes the recent Italian experience in the field of environmental taxes and subsidies to highlight the opportunities and challenges for future initiatives. This effort seems to be useful advice to narrow the gap between the recurrent claims to implement environmental fiscal reforms, and the implementation phase, often jeopardized by low political acceptability and practicability.

As a general finding, one deems that a more decisive reallocation process, to be effective and politically viable, should rely on three decisive fundamentals.

The first is that of transparency, based on a detailed knowledge of the existing instruments that should be able to raise awareness with policymakers and other stakeholders of their budgetary effects and environmental (de)merits and effectiveness. The elaboration and periodical update of the Catalogue of EnvironmentallyFriendly and Harmful Subsidies represent, from this point of view, a milestone that could also be supplemented by more in-depth knowledge of fiscal levies related to the environment currently implemented at the national and local level. Also the recent participation of Italy to the G20 fossil fuel subsidies peer reviews (coupled with Indonesia) provides important reform options to be taken into consideration (OECD, 2019).

The second is that of graduality and predictability, i.e., the capacity to keep a gradual but reliable and predictable pace towards the final goals of the reform process. Gradual but predictable evolutionary paths can be applied, for example, to the progressive reduction, towards full auctioning, of free allocation of ETS allowances, or to the alignment of diesel and gasoline taxes to better reflect externalities caused by their consumption.

The third one is represented by the capacity to design and include EFRs within more general strategies for sustainable development to exploit synergies and support policy coherence while taking account of potential trade-offs. Policy packages, well-designed compensation measures, and their consideration within wider reforms of the overall financial system may represent, in this direction, the most promising tools to govern the main (real or perceived) trade-offs between environmental, social, and economic policy objectives.

For the future, the main research interest in this field will go to the follow-up of the Italian experience within the more general European framework, with a specific focus on two ongoing processes. On the one hand, the Green Deal launched by the European Commission in December 2019, where well designed fiscal reform and greater use of green budgeting will help to redirect public investment, consumption, and taxation to green priorities. On the other hand, the drafting of the Multiannual Financial Framework (MFF) and the ongoing evaluation process of the Energy Tax Directive, where climate and environmental objective should assume a central role in the allocation of funds and definition of minimum rates. A better knowledge of priorities, opportunities, and barriers regarding the Italian case can represent, in this perspective, a useful contribution to enhance effective and coherent EFRs in the European context.

\section{AUTHOR CONTRIBUTIONS}

Conceptualization: Andrea Zatti.

Data curation: Andrea Zatti.

Formal analysis: Andrea Zatti.

Funding acquisition: Andrea Zatti.

Investigation: Andrea Zatti.

Methodology: Andrea Zatti.

Project administration: Andrea Zatti.

Resources: Andrea Zatti.

Software: Andrea Zatti.

Supervision: Andrea Zatti. 
Validation: Andrea Zatti.

Visualization: Andrea Zatti.

Writing - original draft: Andrea Zatti.

Writing - review \& editing: Andrea Zatti.

\section{REFERENCES}

1. Camporeale, C., Grassi, L., \& Molocchi, A. (2018). The diesel fuel excise duty gap as compared to gasoline: an environmental coherence assessment through the external costs approach. Presented at the Sixth Annual Conference of the Italian Association of Environmental and Resource Economist (IAERE) in Turin 15th - 16th February 2018. Retrieved from https://www.iaere. org/conferences/2018/files/camporeale.pdf

2. Carraro, F., \& Zatti, A. (2012). Decentralized Environmental Taxation: A Preliminary Assessment (Chapter 3). In L. Kreiser, A. Y. Sterling, P. Herrera, J. E. Milne, \& H. Ashiabor (Eds.), Critical Issues in Environmental Taxation (pp. 33-49). https://doi.org /10.4337/9781781952191.00013

3. Ekins, P. (1999). European environmental taxes and charges: recent experience, issues and trends. Ecological Economics, 31(1), 39-62. https://doi.org/10.1016/S09218009(99)00051-8

4. Eunomia. (2014). Study on Assessing the Environmental Fiscal Reform Potential in 12 EU Member States (Final report to DG Environment of the European Commission). Retrieved from https://www. eunomia.co.uk/reports-tools/environmental-fiscal-reform-potentialin-12-eu-member-states/

5. Eunomia. (2016). Study on Assessing the Environmental Fiscal Reform Potential for the EU28 (Final report for the European Commission). Retrieved from https://www.eunomia.co.uk/reports-tools/study-onassessing-the-environmental-fiscalreform-potential-for-the-eu28/

6. European Commission (EC). (1993a). Towards sustainability. A European Community programme of policy and action in relation to the environment and sustainable development. Retrieved from https:// ec.europa.eu/environment/archives/ action-programme/env-act5/ pdf/5eap.pdf

7. European Commission (EC). (1993b). Growth, Competitiveness, Employment: The Challenges and Ways Forward into the $21^{\text {st }}$ Century (White Paper). Bulletin of the European Communities, Supplement 6/93, European Commission, Brussels. Retrieved from http://aei.pitt.edu/1139/1/ growth_wp_COM_93_700_ Parts_A_B.pdf

8. European Commission (EC). (1997). Tax provisions with a potential impact on environmental protection. Luxembourg. Retrieved from https://op.europa.eu/en/publicationdetail/-/publication/84600beb5e3b-4ebc-9651-a610078c50c6/ language-en

9. European Commission (EC). (2001). Environment 2010: Our future, Our choice - The Sixth Environment Action Programme. Brussels. Retrieved from https://ec.europa.eu/ environment/air/pdf/6eapbooklet_ en.pdf

10. European Commission (EC). (2007a). GREEN PAPER on marketbased instruments for environment and related policy purposes. COM (2007) 140 final. Brussels. Retrieved from https://ec.europa.eu/taxation customs/sites/taxation/files/resources/documents/common/whats_new/ com\%282007\%29140_en.pdf

11. European Commission (EC). (2007b). Commission Staff Working Document Accompanying the GREEN PAPER on market-based instruments for environment and related policy purposes. SEC (2007) 388. Brussels. Retrieved from https:// secure.ipex.eu/IPEXL-WEB/dossier/ document.do ? code $=$ SEC\&year $=200$ $7 \&$ number $=388 \&$ extension $=$ FIN

12. European Commission (EC). (2010). Communication from the Commission. EUROPE 2020. A strategy for smart, sustainable and inclusive growth. COM (2010) 2020 final. Brussels. Retrieved from https://eur-lex. europa.eu/legal-content/en/ALL /?uri=CELEX\%3A52010DC2020

13. European Commission (EC). (2019). The Environmental Implementation Review 2019 (Country Report - Italy). SWD (2019) 123 final. Retrieved from https://ec.europa. eu/environment/eir/pdf/report_it_ en.pdf

14. European Court of Auditors. (2017). Greening: a more complex income support scheme, not yet environmentally effective (Special Report No. 21). Luxembourg. Retrieved from https://www.eca. europa.eu/Lists/ECADocuments/ SR17_21/SR_GREENING_EN.pdf

15. European Environment Agency (EEA). (2006). Using the market for cost-effective environmental policy (EEA Report). Copenhagen: EEA. Retrieved from https://www.eea. europa.eu/publications/eea_report_2006_1

16. European Environment Agency (EEA). (2011a). Environmental fiscal reform: illustrative potential in Italy. Prepared for the conference "Environmentally-related taxation and fiscal reform". Retrieved from https://www.eea.europa.eu/highlights/fiscal-reform-can-create-jobs/ EEABriefingNoteforETRWorkshop_Rome.pdf

17. European Environment Agency (EEA). (2011b). Environmental tax reform in Europe: implications for income redistribution (EEA Technical Report No. 16/2011). Copenhagen. Retrieved from https://www.eea.europa.eu/publications/environmental-tax-reform-ineurope

18. European Environment Agency (EEA). (2015). Monitoring $\mathrm{CO}_{2}$ emissions from new passenger cars and vans in 2014 (EEA Technical Report No. 16/20115). Copenhagen. 
Retrieved from https://www.eea. europa.eu/publications/monitoringemissions-cars-and-vans/download

19. European Environment Agency (EEA). (2016). Environmental taxation and EU environmental policies (EEA Report No. 17/2016). Copenhagen. Retrieved from https://www.eea.europa.eu/publications/environmental-taxation-andeu-environmental-policies

20. Eurostat. (2018). Taxation trends in the European Union. Luxembourg. Retrieved from https://ec.europa. eu/taxation_customs/sites/taxation/ files/taxation_trends_report_2018. pdf

21. EU (n.d.). Council recommendations on Italy 2012 2013, 2014, 2015, 2017 National Reform Programmes (NRPs) within the European Semester.

22. Fullerton, D. A., Leicester, S., \& Smith, S. (2008). Environmental taxes (NBER Working Paper No. 14197). National Bureau of Economic Research. Retrieved from https://www.researchgate.net/ publication/5189204_Environmental_Taxes

23. Gestore Servizi Energetici (GSE). (2019). Rapporto delle attività 2018. Roma. (In Italian). Retrieved from https://www.gse.it/documenti_site/ Documenti\%20GSE/Rapporti\%20 delle\%20attivit\%C3\%A0/GSE RA2018.pdf

24. Gruppo di Lavoro sull'Erosione Fiscale. (2011). Relazione Finale. Roma. (In Italian). Retrieved from http://www.mef.gov.it/primo-piano/ documenti/20111229/Relazione_finale_del_gruppo_di_lavoro_sullxerosione_fiscale.pdf

25. Harding, M. (2014). Personal Tax treatment of Company Cars and Commuting Expenses: Estimating the Fiscal and Environmental Costs (OECD Taxation Working Papers No. 20). Paris, OECD Publishing. https://doi. org/10.1787/5jz14cg1s7vl-en

26. Impact Assessment Office. (2017a). Fiscal Expenditures. Incentives, deductions and exemptions: how many exist? Who benefits from them? Senate of the Italian Republic, Focus. Retrieved from http://www. senato.it/service/PDF/PDFServer/ BGT/01077473.pdf
27. Impact Assessment Office. (2017b). Does the polluter pay? The social cost of pollution caused by economic activities and environmental taxes in Italy. Senate of the Italian Republic Focus. Retrieved from http://www. senato.it/service/PDF/PDFServer/ BGT/01078701.pdf

28. Institute for European Environmental Policy (IEEP). (2014). Environmental Tax Reform in Europe: Opportunities for the future (Final Report for The Netherlands Ministry of Infrastructure and the Environment). Brussels. Retrieved from http://minisites.ieep.eu/assets/1397/ETR_in_Europe_-_Final_report_of_IEEP_study_-_30_ May_2014.pdf

29. Kosonen, K. (2010). Why are environmental tax revenues falling in the European Union? In C. D. Soares, J. E. Milne, H. Ashiabor, L. Kreiser, \& K. Deketelaere (Eds.), Critical issues in Environmental Taxation. Oxford: Oxford University Press.

30. Lapecorella, F., \& Douvan, A. R. (2014). A green tax reform in times of financial economic crisis. The Italian Attempts 2012 and 2014. Presented in GCET 2014, Copenhagen. Retrieved from https://conferences.au.dk/fileadmin/ conferences/gcet/Presentations_in the_detailed_programme/H_097_ Ravazzi-Lapecorella_Italy_GCET_ Copenhagen_25-09-2014.pdf

31. Leicester, A. (2006). The UK tax system and the environment. The Institute of Fiscal Studies. London. https://doi.org/10.1920/ re.ifs. 2006.0068

32. Ministere de l'Environnement, de l'Energie et de la Mer. (2017). Fiscalite environnementale. Un etat des lieux. Paris, Janvier. (In French). Retrieved from http://temis. documentation.developpementdurable.gouv.fr/docs/Temis/0086/ Temis-0086030/22911.pdf

33. Ministry of the Environment, Land and Sea. (2016). Italian Catalogue of Environmentally Friendly Subsidies and Environmentally Harmful Subsidies. Synthesis, Rome. Retrieved from https://www. oneplanetnetwork.org/sites/default/ files/italy_catalogue_ehs_efs_synthesis_eng.pdf
34. Ministry of the Environment, Land and Sea. (2018). Italian Catalogue of Environmentally Friendly Subsidies and Environmentally Harmful Subsidies 2017. Synthesis. Rome.

35. OECD (2019). Italy's effort to phase out and rationalise its fossil-fuel subsidies (A report on the G20 Peer-review of inefficient fossilfuel subsidies that encourage wasteful consumption in Italy). Retrieved from https://www.greengrowthknowledge.org/resource/ italy $\% \mathrm{E} 2 \% 80 \% 99$ s-effort-phaseout-and-rationalise-its-fossil-fuelsubsidies

36. OECD. (1989). Economic instruments for environmental protection. Paris. Retrieved from https://www.worldcat.org/title/ economic-instruments-for-environmental-protection/oclc/21763569

37. OECD. (1991). Environmental policy: how to apply economic instruments. Paris. https://doi. org/10.1177/027046769301300474

38. OECD. (1993). Taxation and the environment: complementary policy. Paris. https://doi.org/10.1016/03014207(94)90008-6

39. OECD. (1994). Managing the environment: the role of economic instruments. Paris. Retrieved from https://www.amazon.com/Managing-Environment-Role-EconomicInstruments/dp/9264141367

40. OECD. (1995). Environmental fiscal reform for poverty reduction. Retrieved from https://www.oecd. org/greengrowth/green-development/34996292.pdf

41. OECD. (1996). Implementation strategies for environmental taxes. Paris. Retrieved from https://portals. iucn.org/library/node/27272

42. OECD. (1997). Environmental taxes and green tax reform. Paris. Retrieved from https://books.google. com.ua/books/about/Environmental_Taxes_and_Green_Tax_Reform. html?id=cfKzAAAAIAAJ\&redir esc $=\mathrm{y}$

43. OECD. (2001). Environmentally related taxes in OECD countries. Paris. Retrieved from https://www. cbd.int/financial/fiscalenviron/gfiscaltaxes-oecd.pdf

44. OECD. (2006). The political economy of environmentally 
related taxes. Paris. https://doi. org/10.1787/9789264025530-en

45. OECD. (2013). Taxing energy use: a graphical analysis. Paris. https://doi. org/10.1787/9789264183933-en

46. OECD. (2017). Environmental fiscal reform. Progress, prospects and pitfalls (OECD report for the G7 Environment Ministers). Paris. Retrieved from http://www.greenfiscalpolicy.org/policy-insights/environmental-fiscal-reform-progressprospects-and-pitfalls-oecd/

47. OECD. (2018). OECD Companion to the Inventory of Support Measures for Fossil Fuels 2018. Paris. Retrieved from https://www.oecd.org/environment/oecd-companion-to-the- inventory-of-support-measures-forfossil-fuels-2018-9789264286061-en. htm

48. Parry, I., Heine, D., Lis, E., \& Li, S. (2014). Getting Energy Prices Right. From Principles to Practices. International Monetary Fund. Washington. Retrieved from https://www.elibrary. imf.org/doc/IMF071/211719781484388570/21171

9781484388570/Other_formats/ Source_PDF/21171-9781498309035. pdf

49. Vollebergh, H. (2014). Green tax reform: Energy tax challenges for the Netherlands. PBL Netherlands Environmental Assessment Agency, The Hague. Retrieved from https:// www.pbl.nl/sites/default/files/ downloads/pbl-2015-green-taxenergy-tax-challenges-for-the-netherlands-1501.pdf

50. Zatti, A. (2017). Verso una riallocazione verde dei bilanci pubblici. Pavia University Press. (In Italian). Retrieved from http:// archivio.paviauniversitypress.it/ oa/9788869520570.pdf

51. Zatti, A. (2019). Environmental taxes and green fiscal reform in Italy: An update. Economics and policy of energy and the environment, 1, 31-67. Retrieved from https:// www.researchgate.net/publication/331420426_Environmental_taxes_and_green_fiscal_reform_ in_Italy_An_update 